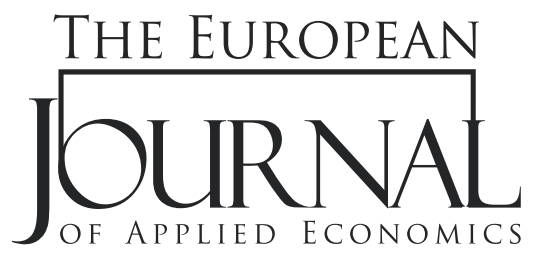

EJAE 2018, 15(2): 17-28

ISSN 2406-2588

UDK: $336.228: 330.34(497.11+497.5)$

330.34

DOI: 10.5937/EJAE15-18056

Original paper/Originalni naučni rad

\title{
THE RELATIONSHIP BETWEEN TAXES AND ECONOMIC GROWTH: EVIDENCE FROM SERBIA AND CROATIA
}

\author{
Branimir Kalaš*, Vera Mirović, Nada Milenković \\ University of Novi Sad, Faculty of Economics, \\ Subotica, Serbia
}

\begin{abstract}
:
This study presents an empirical analysis of taxes and economic growth in Serbia and Croatia in the period 2007-2016. In order to identify the impact of tax forms on economic growth and their relationship, the authors decided to set up a panel regression where gross domestic product is the dependent variable, while corporate income tax, value added tax, social security contributions and excises are independent variables. The results of random effect model have shown that corporate income tax, value added tax and social security contributions have a positive impact on the gross domestic product, while excises affect the gross domestic product negatively. However, only value added tax has a statistically significant impact on economic growth in these countries, with each increase in revenue from this tax contributing to the growth of gross domestic product in the observed period.
\end{abstract}

\section{Article info:}

Received: July 29, 2018

Correction: August 24, 2018

Accepted: August 29, 2018

\section{Keywords:}

taxes,

economic growth, relationship,

Serbia,

Croatia.

\section{INTRODUCTION - THEORETICAL BACKGROUND}

Economic growth is the basis of increased prosperity (Myles, 2000). Taxes are important tool for the economy. They represent the crucial component in contemporary business and their relevance is manifested through stability and predictability (Kalaš et al. 2016). There are many definitions of taxes (Anyanwu, 1993; Bhartia, 2009; Appah and Oyandonghan 2011; Angahar and Alfred, 2012; Chigbu et al. 2012; Salami et al. 2015). Appah (2010) defined tax as a compulsory levy imposed on a subject or his/her property by the government to provide social amenities and create conditions for the economic prosperity of the society. Likewise, Chigbu and Njoku (2015) emphasize that taxation is a major source of revenue for every economy and it's usually an instrument used in reducing the gap between the rich 
and the poor. Taxes should be "good" for the economy and its development. Mitra and Stern (2003) determined an optimal tax level and structure that could contribute to the more efficient growth of the economy. Likewise, Mankiw et al. (2009) defined optimal taxation theory in terms of the fact that an adequately designed tax system can maximize a social welfare function. In the academic world, there is a voluminous literature on taxes and their growth features, as well as on widely varying methodologies and results (Gale et al. 2015). For example, McBride (2012) shares results of Congressional Research Service, which has found support for the theory that taxes have no effect on economic growth by relying on the U.S. experience since World War II, where they found that a rapid economic growth occurred in the 1950s when the top rate was more than $90 \%$. Table 1 reflects empirical studies which examined the effects of tax forms on economic growth.

\begin{tabular}{|c|c|c|c|c|c|}
\hline & Year & $\begin{array}{l}\text { Time } \\
\text { period }\end{array}$ & Country & Effect & Result \\
\hline Helms & 1985 & 1965-1979 & United States & Negative & $\begin{array}{l}\text { Revenue used to fund transfer pay- } \\
\text { ments slows growth }\end{array}$ \\
\hline $\begin{array}{l}\text { Padovano and } \\
\text { Galli }\end{array}$ & 2001 & $1951-1990$ & $\begin{array}{l}23 \text { OECD } \\
\text { countries }\end{array}$ & Negative & $\begin{array}{l}\text { Effective marginal income tax rates } \\
\text { are negatively correlated with GDP } \\
\text { growth }\end{array}$ \\
\hline Tomljanovich & 2004 & $1960-1990$ & United States & Negative & $\begin{array}{l}\text { Higher tax rates negatively affect } \\
\text { short-run growth, but not long-run } \\
\text { growth }\end{array}$ \\
\hline $\begin{array}{l}\text { Lee and } \\
\text { Gordon }\end{array}$ & 2005 & 1980-1997 & 70 countries & Negative & $\begin{array}{l}\text { Reducing corporate income tax by } \\
1 \% \text { raises annual growth by } 0.1 \% \text { to } \\
0.2 \%\end{array}$ \\
\hline $\begin{array}{l}\text { Tosun and } \\
\text { Abizadeh }\end{array}$ & 2005 & 1980-1999 & $\begin{array}{l}\text { OECD } \\
\text { countries }\end{array}$ & $\begin{array}{l}\text { positive/ } \\
\text { negative }\end{array}$ & $\begin{array}{l}\text { Shares of personal and property taxes } \\
\text { have responded positively to econom- } \\
\text { ic growth, while the shares of payroll } \\
\text { and goods and services taxes have re- } \\
\text { flected a relative decline }\end{array}$ \\
\hline $\begin{array}{l}\text { Bania, Gray } \\
\text { and Stone }\end{array}$ & 2007 & 1962-1997 & United States & Negative & $\begin{array}{l}\text { Taxes directed towards public invest- } \\
\text { ments were first added then subtract- } \\
\text { ed from GDP }\end{array}$ \\
\hline Reed & 2008 & 1970-1999 & United States & Negative & $\begin{array}{l}\text { Robust negative effect of state and } \\
\text { local taxation }\end{array}$ \\
\hline $\begin{array}{l}\text { Alesina and } \\
\text { Ardagna }\end{array}$ & 2010 & $1970-2007$ & $\begin{array}{l}\text { OECD } \\
\text { countries }\end{array}$ & Negative & $\begin{array}{l}\text { Fiscal incentives based on tax cuts en- } \\
\text { hance growth more than increased } \\
\text { consumption }\end{array}$ \\
\hline \multirow{2}{*}{$\begin{array}{l}\text { Gemmell, } \\
\text { Kneller and } \\
\text { Sanz }\end{array}$} & \multirow[t]{2}{*}{2011} & \multirow[t]{2}{*}{ 1970-2004 } & \multirow{2}{*}{$\begin{array}{l}17 \text { OECD } \\
\text { countries }\end{array}$} & \multirow[t]{2}{*}{ Negative } & $\begin{array}{l}\text { Taxes on income and profit are most } \\
\text { damaging to economic growth over } \\
\text { the long run. }\end{array}$ \\
\hline & & & & & $\begin{array}{l}\text { The second in line are consumption } \\
\text { taxes }\end{array}$ \\
\hline $\begin{array}{l}\text { Romer and } \\
\text { Romer }\end{array}$ & 2010 & $1945-2007$ & United States & Negative & $\begin{array}{l}\text { Tax increase of } 1 \% \text { GDP leads to a } \\
\text { fall in output of } 3 \% \text { after about two } \\
\text { years }\end{array}$ \\
\hline
\end{tabular}




\begin{tabular}{|c|c|c|c|c|c|}
\hline $\begin{array}{l}\text { Arnold, Brys, } \\
\text { Heady, Johans- } \\
\text { son, Schwelnuss } \\
\text { and Vartia }\end{array}$ & 2011 & 1971-2004 & $\begin{array}{l}21 \text { OECD } \\
\text { countries }\end{array}$ & Negative & $\begin{array}{l}\text { Corporate taxes are most harmful, } \\
\text { followed by personal income tax, } \\
\text { consumption and property tax }\end{array}$ \\
\hline $\begin{array}{l}\text { Barro and } \\
\text { Redlick }\end{array}$ & 2011 & $1912-2016$ & United States & Negative & $\begin{array}{l}\text { Cut in the average marginal tax rate of } \\
1 \% \text { raises GDP per capita by around } \\
0.5 \text { in the next year }\end{array}$ \\
\hline $\begin{array}{l}\text { Ferede and } \\
\text { Dahlby }\end{array}$ & 2012 & 1977-2006 & Canada & Negative & $\begin{array}{l}\text { Reducing corporate income tax by } \\
1 \% \text { raises annual growth by } 0.1 \text { to } \\
0.2 \%\end{array}$ \\
\hline $\begin{array}{l}\text { Ibadin and } \\
\text { Oladipupo }\end{array}$ & 2015 & 1981-2014 & Nigeria & Positive & $\begin{array}{l}\text { Value added tax and petroleum profit } \\
\text { tax have a positive and significant } \\
\text { relationship on the gross domestic } \\
\text { product }\end{array}$ \\
\hline $\begin{array}{l}\text { Onakoya and } \\
\text { Afintinni }\end{array}$ & 2016 & 1980-2013 & Nigeria & $\begin{array}{l}\text { positive/ } \\
\text { negative }\end{array}$ & $\begin{array}{l}\text { There is a significant positive relatio- } \\
\text { nship between petroleum profit tax, } \\
\text { company income tax and economic } \\
\text { growth. Insignificant relationship was } \\
\text { perceived between customs, excises } \\
\text { and economic growth }\end{array}$ \\
\hline
\end{tabular}

Table 1. Empirical studies about the effects of taxes on economic growth

Source: Adapted from McBride (2012)

\section{TAX TRENDS IN SERBIA AND CROATIA}

Tax systems of modern countries differ from each other in terms of constituent elements and the share of tax forms (Aničić et al. 2012). Perre and Hashorva (2011) argued that tax systems in West Balkan countries are similar and founded on three main types of taxes: personal income tax, corporate income tax and value added tax. Šimović et al. (2014) defined Croatian tax system as a hybrid where the elements of income-based and consumption-based taxation concept are present. Right on, Arbutina (2000) cited that value added tax has been applied for a short period of time in Croatia, but at the moment it's the cornerstone of the state revenue. For Serbia, Ranđelović (2008) determined the significance of direct taxes in transition countries, while personal income tax is perceived to be a fundamental element of modern tax systems in developed countries. On the other hand, Stevanović and Gajić (2013) noticed that tax system in Serbia is not efficient enough and needs to be characterised by simplicity in terms of efficient administration, low costs electronic business and flexibility through the fact that tax legislation should follow the economic justification. Also, the existence of political responsibility and fairness represents an essential principle which provides a clear and equal approach in terms of paying taxes and economic power. Nerre et al. (2014) argued that Serbian tax system has been continuously improving since the start of the transition in 2000, where total revenue expressed as a percentage of GDP has risen from $33 \%$ in 2000 to $42 \%$ in 2012 . Also, they determined social security contributions as the main source of tax revenues. 


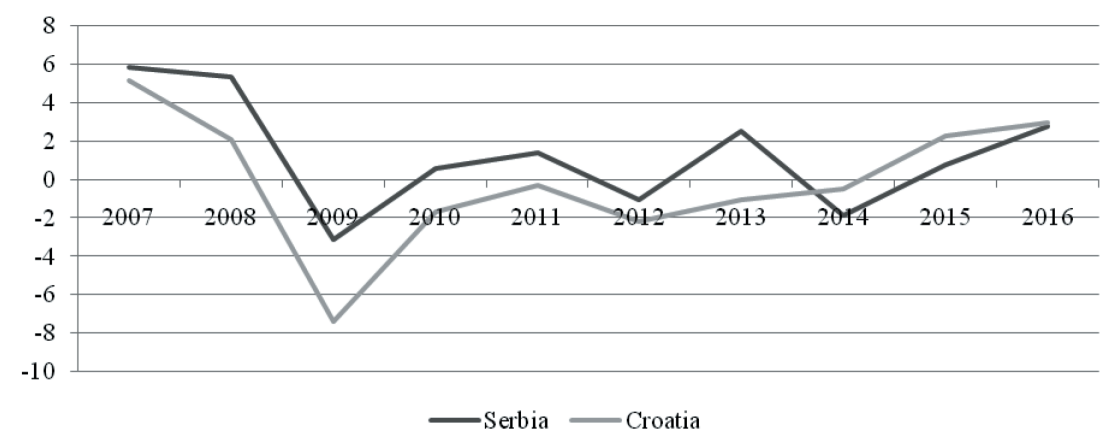

Figure 1. GDP growth rate in Serbia and Croatia from 2007 to 2016

Source: Authors based on http://www.imf.org/external/country

Figure 1 manifests the annual rate of GDP growth in selected countries from 2007 to 2016. First, in Serbia, rates were above 5\% in 2007 and 2008, while the largest drop of 3.12\% was recorded in 2009, as a result of decreasing economic activity in the world and escalating global economic crisis. Then, in the next two years, there is a slight increase of this indicator after which Serbian economy achieved a negative rate of $1.01 \%$. A similar trend was reported in 2014 when the growth rate of gross domestic product amounted $1.83 \%$, but in the last two years, the average growth rate was $1.24 \%$ in Serbia. On the other hand, Croatia had a similar trend of gross domestic product, while in 2009 their decrease was higher than in Serbia, and recorded a negative rate of 7.38\%. Further on, Croatian economy had negative rates and average decline amounted $2.16 \%$ until 2015 when a slight growth of $1.65 \%$ was recorded.

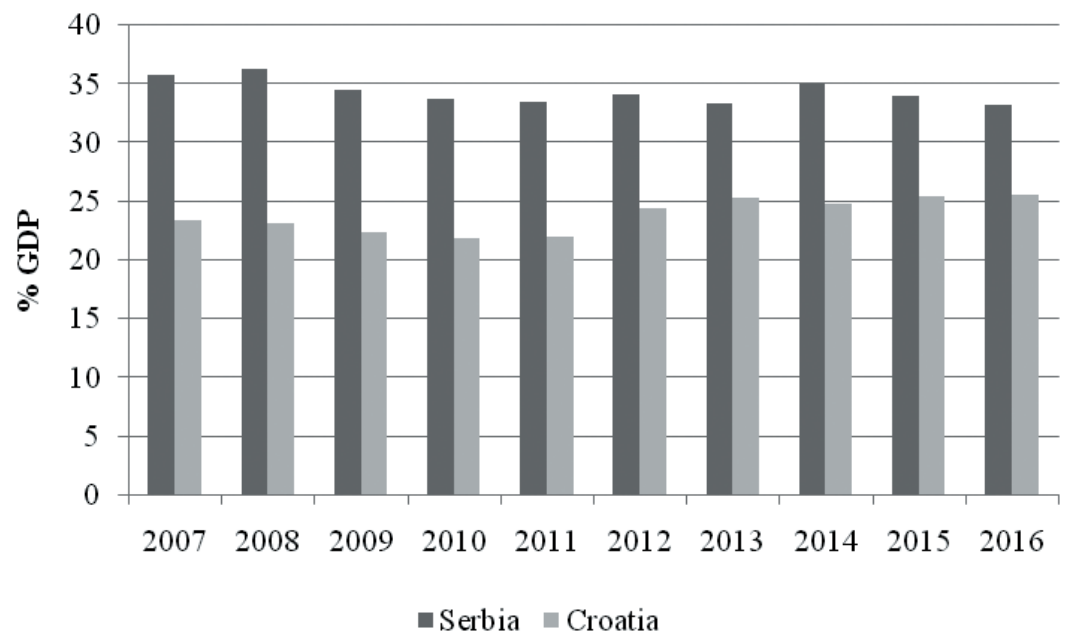

Figure 2. Tax revenues in Serbia and Croatia from 2007 to 2016

Source: Authors based on http://www.imf.org/external/country

Looking at the tax revenue's share of GDP, it is higher in Serbia compared to Croatia. At the beginning, tax revenues constituted 35.8\% of gross domestic product in Serbia and 25.7\% in Croatia, where the share of tax revenues declined until 2010 and 2011. Also, there was an increase of tax revenue's 
share of $0.4 \%$ in Serbia, while in 2012 it recorded a similar growing trend by $0.9 \%$ in Croatia. Comparing the average share of tax revenues, it amounts to $34.61 \%$ and $24.49 \%$ of the gross domestic product respectively, which indicates that there is a disparity of around $10 \%$ in observed variables between the selected countries.
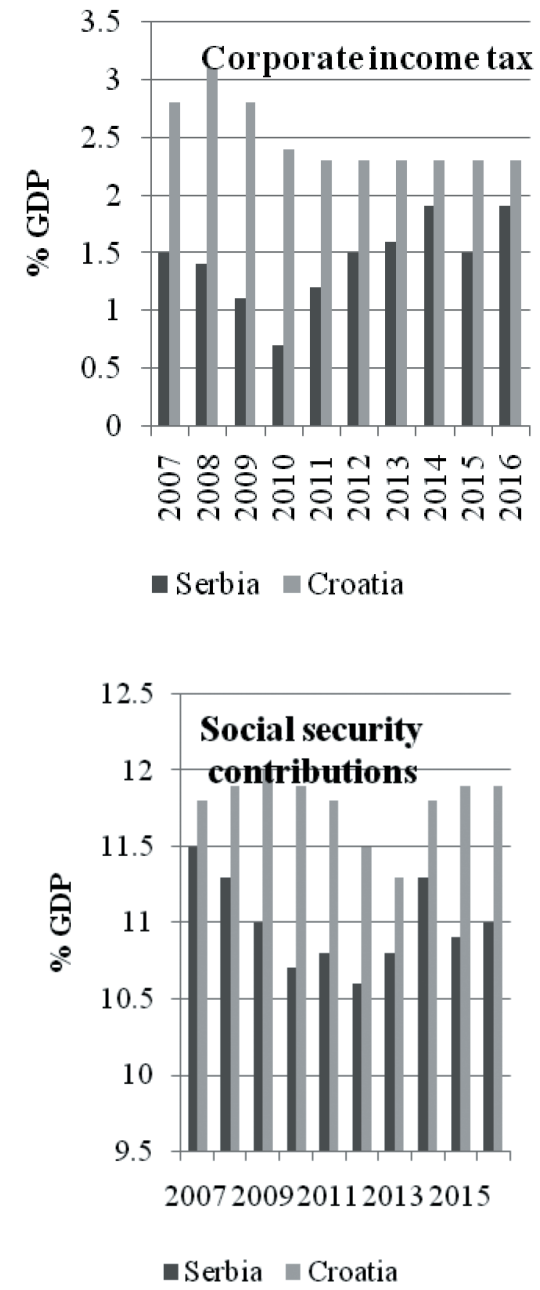
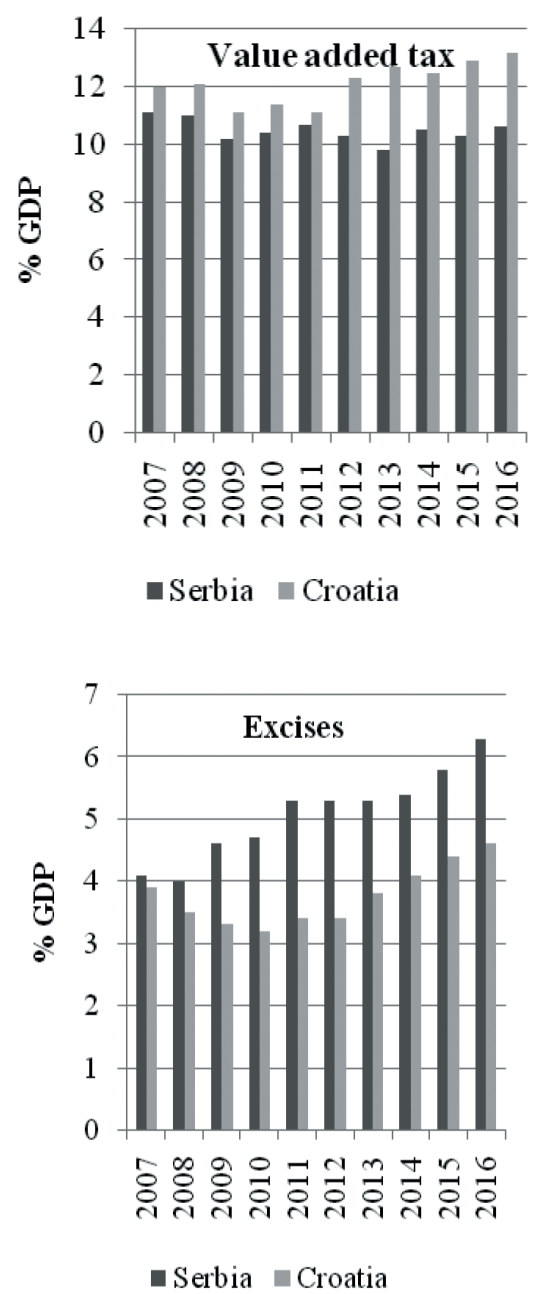

Figure 3. Comparative review of tax forms in Serbia and Croatia Source: Authors based on http://www.imf.org/external/country

Figure 3 represents a comparative review of tax form's share in the gross domestic product in Serbia and Croatia from 2007 to 2016. First, personal income tax share is around 4\% in Serbia and 6\% in Croatia, with a noticeable declining trend in both countries. In fact, since the beginning of the period, the share of this tax form is reduced to $1.2 \%$ in Serbia and $0.8 \%$ in Croatia. On the other hand, corporate income tax share increased by $0.6 \%$ in Serbia, while in Croatia it recorded a decline of $0.4 \%$. Ranđelović (2010) emphasizes that average share of the corporate income taxes in GDP of Serbia is 2, 5 to 3 times lower than in the European Union. Value added tax is one of the most abundant tax forms in selected countries and share of this tax exceeds $10 \%$ of the gross domestic product. At the end of 2016, the share of value added tax amounted $10.6 \%$ in Serbia and 13\% in Croatia. Further, social security contributions represent tax form with a share of around $11 \%$ and $12 \%$. However, there was a reduction of this tax for 
$0.4 \%$ in Serbia and $1.6 \%$ in Croatia, in the observed period. Finally, excise share is higher in Serbia than Croatia, where it has a completely different trend. Since 2007 , the share of this tax form is increased by $1.9 \%$ in Serbia, while in Croatia it has recorded a decline of $0.2 \%$. Looking at the observed tax forms, it is evident that Croatia has a greater share of taxes in the gross domestic product, except in case of excise, which is higher in Serbia. On the other hand, an interesting fact is that tax revenues in Serbia make almost $40 \%$ of the gross domestic product, while in Croatia it is only $30 \%$. It can be assumed that other tax types in Serbia have a greater share in the gross domestic product.

\section{METHODOLOGY AND DATA}

The research is focused on tax forms and their relation to the gross domestic product, which is defined as a proxy for economic growth. The analysis is conducted for the period covering 10 years as of 2007 to 2016 in Serbia and Croatia, where the authors used percentage share of GDP from the official data of International Monetary Fund. The paper used a multiple regression by means of which they studied the nature of the presented relationship. Likewise, there is an analysis of variance and multicollinearity between the independent variables through Variance Inflation Factor test (VIF).

\begin{tabular}{lccc}
\hline \multicolumn{1}{c}{ Variable } & Notation & Calculation & Source \\
\hline Dependent variable & & & \\
\hline Gross domestic product & GDP & \% annual growth rate & IMF report \\
\hline Independent variables & & & \\
\hline Corporate income tax & CIT & \% share of GDP & IMF report \\
\hline Value added tax & VAT & \% share of GDP & IMF report \\
\hline Social security contributions & SSC & \% share of GDP & IMF report \\
\hline Excises & EXC & \% share of GDP & IMF report \\
\hline
\end{tabular}

Table 2. Variable definition

Source: Authors review

The paper represents a regression model, which includes one dependent variable and four independent variables. First, a gross domestic product was used as a proxy for economic growth while tax forms were defined by the next schedule: corporate income tax as CIT, value added tax as VAT, social security contributions as SSC and excises as EXC.

In the presented study we have used a random effects model due to its capability to account for the correlation among the residuals. Hausman test confirmed that this type of modeling option is appropriate for the analysis. The random effects model is specified as follows:

$$
G D P_{i t}=\beta_{0}+\mu_{i}+\beta_{1} C I T_{i t}+\beta_{2} V A T_{i t}+\beta_{3} S S C_{i t}+\beta_{4} E X C_{i t}+\varepsilon_{i t}
$$

where $\mathrm{GDP}_{i t}$ stands for gross domestic product of country ${ }_{\mathrm{i}}$ [Serbia, Croatia] for period ${ }_{\mathrm{t}}$ [2007-2016], $\mathrm{CIT}_{\text {it }}$ stands for corporate income tax as $\%$ of GDP, VAT $_{\text {it }}$ for value added tax as $\%$ of GDP, SSC $_{\text {it }}$ for 
social security contributions as $\%$ of GDP, $\mathrm{EXC}_{\mathrm{it}}$ for excises as $\%$ of GDP, $\beta_{0}$ for the grand intercept, $\beta_{\mathrm{i}}$ for the coefficients with the independent variables, $\varepsilon_{i t}$ for the error term and $\mu_{\mathrm{i}}$ for the random effect pertaining to the countries.

\section{RESULT RESEARCH}

Taking into account that research examines tax effect on economic growth in Serbia and Croatia, the authors applied panel regression model with the gross domestic product as the dependent variable and four independent variables such as corporate income tax, value added tax, social security contributions and excises. At first, we presented descriptive statistics of explanatory variables, as well as mean, standard deviation and minimum and maximum level.

\begin{tabular}{|c|c|c|c|c|c|}
\hline Country & GDP & CIT & VAT & SSC & EXC \\
\hline \multicolumn{6}{|c|}{ Serbia } \\
\hline Mean & 1.34 & 1.43 & 10.49 & 10.99 & 5.08 \\
\hline Std. Dev. & 2.92 & 0.36 & 0.38 & 0.29 & 0.72 \\
\hline Min. & -3.12 & 0.7 & 9.8 & 10.6 & 4 \\
\hline Max. & 5.89 & 1.9 & 11.1 & 11.5 & 6.3 \\
\hline \multicolumn{6}{|c|}{ Croatia } \\
\hline Mean & -0.07 & 2.49 & 12.13 & 11.78 & 3.76 \\
\hline Std. Dev. & 3.47 & 0.29 & 0.74 & 0.21 & 0.48 \\
\hline Min. & -7.38 & 2.3 & 11.1 & 11.3 & 3.2 \\
\hline Max. & 5.15 & 3.1 & 13.2 & 12 & 4.6 \\
\hline \multicolumn{6}{|c|}{ Total } \\
\hline Mean & 0.64 & 1.96 & 11.31 & 11.38 & 4.42 \\
\hline Std. Dev. & 3.20 & 0.63 & 1.02 & 0.48 & 0.9 \\
\hline Min. & -7.38 & 0.7 & 9.8 & 10.6 & 3.2 \\
\hline Max. & 5.89 & 3.1 & 13.2 & 12 & 6.3 \\
\hline
\end{tabular}

Table 3. Descriptive statistics

Source: Authors based on SPSS

Table 3 shows mean, minimum and maximum value of explanatory variables in Serbia and Croatia in the period 2007-2016. The results reflect that Serbia reached mean GDP by 1.34 compared to Croatia which had negative growth rate by 0.07 . Further on, mean share of tax forms are higher in Croatia in relation to Serbia, except excises. Based on the obtained results, the highest standard deviation of gross domestic product and value added tax was in Croatia, while corporate income tax and social security contributions have the lowest variations of the observed variables in Serbia. 


\begin{tabular}{|c|c|c|c|c|c|c|}
\hline & Variables & GDP & CIT & VAT & SSC & EXC \\
\hline \multirow{3}{*}{ GDP } & Pearson Correlation & 1 & -.214 & .135 & .142 & .227 \\
\hline & Sig. (2-tailed) & & .365 & .570 & .551 & .337 \\
\hline & $\mathrm{N}$ & 20 & 20 & 20 & 20 & 20 \\
\hline \multirow{3}{*}{ CIT } & Pearson Correlation & -.214 & 1 & $.726^{* *}$ & $.767^{* *}$ & $-.480^{*}$ \\
\hline & Sig. (2-tailed) & .365 & & .000 & .000 & .032 \\
\hline & $\mathrm{N}$ & 20 & 20 & 20 & 20 & 20 \\
\hline \multirow{3}{*}{ VAT } & Pearson Correlation & .135 & $.726^{* *}$ & 1 & $.799^{* *}$ & $-.536^{*}$ \\
\hline & Sig. (2-tailed) & .570 & .000 & & .000 & .015 \\
\hline & $\mathrm{N}$ & 20 & 20 & 20 & 20 & 20 \\
\hline \multirow{3}{*}{ SSC } & Pearson Correlation & .142 & $.767^{* *}$ & $.799^{* *}$ & 1 & $-.489^{*}$ \\
\hline & Sig. (2-tailed) & .551 & .000 & .000 & & .029 \\
\hline & $\mathrm{N}$ & 20 & 20 & 20 & 20 & 20 \\
\hline \multirow{3}{*}{ EXC } & Pearson Correlation & .227 & $-.480^{*}$ & $-.536^{*}$ & $-.489^{*}$ & 1 \\
\hline & Sig. (2-tailed) & .337 & .032 & .015 & .029 & \\
\hline & $\mathrm{N}$ & 20 & 20 & 20 & 20 & 20 \\
\hline \multicolumn{7}{|c|}{ **. Correlation is significant at the 0.01 level (2-tailed). } \\
\hline \multicolumn{7}{|c|}{ *. Correlation is significant at the 0.05 level (2-tailed). } \\
\hline
\end{tabular}

Table 4. Correlation matrix

Source: Authors based on SPSS

Based on the results, it can be concluded that there is no significant relationship between tax forms and gross domestic product. Also, there is a strong positive and significant correlation between corporate income tax (CIT), value added tax (VAT) and social security contributions (SSC). On the other hand, there is a statistically significant correlation between excises and observed tax forms.

\begin{tabular}{ccc}
\hline Variable & VIF & 1/VIF \\
\hline CIT & 5.64 & 0.177303 \\
\hline VAT & 3.41 & 0.292864 \\
\hline SSC & 2.19 & 0.457391 \\
\hline EXC & 2.18 & 0.458307 \\
\hline Mean $V I F$ & & 3.36 \\
\hline
\end{tabular}

Table 5. Multicollienarity test

Table 6 includes VIF test for independent variables where the results show an absence of multicollinearity between them. Namely, the average value of VIF test is 3.36, which is less than the reference value of 10 . 


\begin{tabular}{|c|c|c|c|c|}
\hline \multirow{2}{*}{ Variable } & \multicolumn{2}{|c|}{ RE model } & \multicolumn{2}{|c|}{ FE model } \\
\hline & Coef. & Std. Err. & Coef. & Std. Err. \\
\hline CIT & $\begin{array}{c}1.59 \\
(0.552)\end{array}$ & 2.61 & $\begin{array}{c}-2.13 \\
(0.333)\end{array}$ & 2.20 \\
\hline VAT & $\begin{array}{c}3.09 \\
(0.035)\end{array}$ & 1.32 & $\begin{array}{c}1.15 \\
(0.043)\end{array}$ & 1.09 \\
\hline SSC & $\begin{array}{c}1.54 \\
(0.656)\end{array}$ & 3.37 & $\begin{array}{c}2.16 \\
(0.565)\end{array}$ & 3.76 \\
\hline EXC & $\begin{array}{c}-0.30 \\
(0.827)\end{array}$ & 1.36 & $\begin{array}{c}1.44 \\
(0.242)\end{array}$ & 1.23 \\
\hline _cons & $\begin{array}{l}-53.69 \\
(0.166)\end{array}$ & 36.72 & $\begin{array}{l}-39.19 \\
(0.332)\end{array}$ & 40.38 \\
\hline$R$-square & \multicolumn{2}{|c|}{0.3474} & \multicolumn{2}{|c|}{0.1457} \\
\hline Hausman test & \multicolumn{4}{|c|}{0.3012} \\
\hline Observation & \multicolumn{2}{|c|}{20} & \multicolumn{2}{|c|}{20} \\
\hline
\end{tabular}

Table 6. Model estimation

In order to select an adequate model, Hausman test is included in the analysis, and the results of this test show that random effect model is quite appropriate ( $p$-value $=0.3012$ ). The results of random effect model emphasize that corporate income tax, value added tax and social security contributions have a positive impact on the gross domestic product, while excises negatively affect the gross domestic product. Also, value added tax is an only tax which has a significant impact on the gross domestic product in the analyzed period. Looking at the character of tax effects, value added tax causes the highest change of gross domestic product compared to other taxes. It means that $1 \%$ increase of value added tax raises gross domestic product by $3.09 \%$. These findings are logical because value added tax is the most generous tax in these countries.

\section{CONCLUSION}

Taxes have a fundamental role and place in the economy of each country and they have to be determined at an optimum level in order to provide contribution and prosperity for the economy. The role and impact of taxes on the gross domestic product is widely discussed in the world. There are many types of research which reflected the negative impact on GDP and a small number of research that manifested a positive relationship between taxes and GDP. Using a panel regression model for Serbia and Croatia this paper has shown that there is a positive impact of corporate income tax, value added tax and social security contributions on the gross domestic product, while excises have a negative impact on the gross domestic product. Value added tax is the only tax which has statistically significant impact on the gross domestic product. It is the logical result because value added tax is the most generous tax in Serbia and Croatia. The research confirms previous analysis of observed variables in the world, and the novelty of this paper is reflected in the fact that main tax forms such as personal income tax and corporate income tax do not have significant impact on the gross domestic product. Enabling informative support to policymakers about tax importance and its effects on economic growth 
in the presented countries represents the main contribution of this study. Bearing in mind that value added tax significantly affects the gross domestic product, governments should make additional efforts to increase revenues of this tax form in order to enhance economic growth. Likewise, the presented model gives an empirical contribution to previous studies and provides a possibility to be applied in other countries in the region.

\section{REFERENCES}

Alesina, A., \& Ardagna, S. (2010). Large changes in fiscal policy: taxes versus spending. Tax Policy and the Economy, 24, 35-68. DOI: $10.3386 / \mathrm{w} 15438$

Angahar, P. A., \& Alfred, S. I. (2012). Personal income tax administration in Nigeria: challenges and prospects for increased revenue generation from self employed persons in the society. Global Business and Economics Research Journal, 1(1), 1-11.

Aničić, J., Laketa, M., Radović, B., Radović, D., \& Laketa, L. (2012). Tax policy of Serbia in the function of developing the economic system. UTMS Journal of Economics, 3(1), 33-43.

Anyanwu, J. C. (1993). Monetary Economics: Theory, Policy and Institutions. Onitsha, Nigeria: Hybrid Publishers.

Appah, E., \& Oyandonghan, J.K. (2011). The Challenges of Tax Mobilization and Management in the Nigerian Economy. Journal of Business Administration and Management, 6(2), 128-136.

Arbutina, H. (2000). Value Added Tax in Croatia - An (Almost) Perfect Tax in an Imperfect Environment. Revenue Law Journal, 10(1), 107-118.

Arnold, J., Brys, B., Heady, C., Johansson, A., Schwelnuss, C., \& Vartia, L. (2011). Tax Policy for Economic Recovery and Growth. The Economic Journal, 121(550), 59-80. DOI:10.1111/j.1468-0297.2010.02415.x

Bania, N., Gray, J., \& Stone, J. (2007). Growth, taxes and government expenditures: growth hills for U.S. states. National Tax Journal, 60(2), 193-204.

Barro, R., \& Redlick, C. (2011). Macroeconomic Effects of Government Purchases and Taxes. Quarterly Journal of Economics, 15369, 51-102. DOI:10.3386/w15369

Bhartia, H. L. (2009). Public Finance. New Delhi: Vikas Publishing House PVT Ltd.

Chigbu. E.E, Akujuobi, L. E., \& Appah, E. (2012). An Empirical Study on the Causality Between Economic Growth And Taxation in Nigeria. Current Research Journal of Economic Theory, 4(2), 29-38.

Chigbu, E.E., \& Njoku, C.O. (2015). Taxation and the Nigerian Economy: (1994-2012). Management Studies and Economic Systems, 2(2), 111-128.

Ferede, E., \& Dahlby, B. (2012). The impact of tax cuts on economic growth: Evidence from the Canadian provinces. National Tax Journal, 65(3), 563-594.

Gale, W., Krupkin, A., \& Rueben, K. (2015). The Relationship between Taxes and Growth at the State Level: New Evidence. National Tax Journal, 68(4), 919-942.

Gemmell, N., Kneller, R., \& Sanz, I. (2011). The Timing and Persistence of Fiscal Policy Impacts on Growth: Evidence from OECD Countries. The Economic Journal, 121(550), 33-58. DOI:10.1111/j.1468-0297.2010.02414.x

Helms, L. J. (1985). The Effect of State and Local Taxes on Economic Growth: A Time Series Cross-Section Approach. Review of Economics and Statistics, 67(4), 574-582. DOI:10.2307/1924801

Ibadin, P. O., \& Oladipupo, A. O. (2015). Indirect taxes and economic growth in Nigeria. Ekonomska misao $i$ praksa, 2, 345-364.

International Monetary Fund. (2018). IMF country information. Retrieved April 17, 2018, from http://www.imf. org/external/country

Kalaš, B., Pjanić, M., Milenković, N., \& Andrašić, J. (2016). Comparative Analysis Paying Taxes Indicator: Evidence from Western Balkans Countries and Turkey. International Journal of Management, Accounting and Economics, 3(4), 222-232. 
Lee, Y., \& Gordon, R. (2005). Tax Structure and Economic Growth. Journal of Public Economics, 89(5-6), 10271043. DOI:10.1016/j.jpubeco.2004.07.002

Mankiw, G., Weinzierl, M., \& Yagan, D. (2009). Optimal Taxation in Theory and Practice. Journal of Economic Perspectives, 23(4), 147-174. DOI:10.3386/w15071

McBride, W. (2012). What is the Evidence on Taxes and Growth? Tax Foundation, Special Report 207, December $18,2012$.

Mitra, P., \& Stern, N. (2003). Tax systems in transition. World Bank Policy Research Working Paper 2947. Washington, DC: The World Bank.

Myles, G. (2000). Taxation and Economic Growth. Fiscal Studies, 21(1), 141-168. DOI:10.1111/j.1475-5890.2000. tb00583.x

Nerre, B., Dragojlović, A., Ranđelović, S., \& Đenić, M. (2014). Tax reform in Serbia: Experiences and perspectives. In Tax Reforms: Experiences and Perspectives: Conference Proceedings, 20 Jun 2014 (pp. 79-96). Zagreb: Institute of Public Finance.

Onakoya, A.B., \& Afintinni, O.I. (2016). Taxation and economic growth in Nigeria. Asian Journal of Economic Modelling, 4(4), 199-210.

Padovano, F., \& Galli, E. (2001). Tax rates and economic growth in the OECD countries (1950-1990). Economic Inquiry, 39(1), 44-57. DOI: 10.1111/j.1465-7295.2001.tb00049.x

Pere, E., \& Hashorva, A. (2011). Tax Systems in West Balkans Countries. Romanian Economic and Business Review, 6(2), 80-94.

Ranđelović, S. (2008). Dual Income Tax - An Option for the Reform of Personal Income Tax in Serbia? Economic Annals, 178/179, 183-197.

Ranđelović, S. (2010). Unapređenje performansi poreskog sistema Srbije kroz reformu poreza na dobit. In Poreska politika u Srbiji: Pogled unapred (pp. 75-94). Beograd: USAID Sega projekat. (In Serbian).

Reed, R. (2008). The robust relationship between taxes and U.S. state income growth. National Tax Journal, 61(1), 57-80.

Romer, C., \& Romer, D. (2010). The Macroeconomic Effects of Tax Changes: Estimated Based on a New Measure of Fiscal Shocks. American Economic Review, 100(3), 763-801. DOI:10.3386/w13264

Salami, G.O., Apelogun, K.H., Omidiya, O.M., \& Ojoye, O.F. (2015). Taxation and Nigerian economic growth. Research Journal of Finance and Accounting, 10(6), 93-101.

Stevanović, M., \& Gajić, A. (2013). Analysis of development of the tax system in Serbia. Annals of the Oradea University, 2, 300-304.

Šimović. H., Blažić, J., \& Štambuk, A. (2014). Perspectives of tax reforms in Croatia: expert opinion survey. Financial theory and practice, 38(4), 405-439. DOI:10.3326/fintp.38.4.2

Tomljanovich, M. (2004). The role of state fiscal policy in state economic growth. Contemporary Economic Policy, 22(3), 318-330. DOI:10.1093/cep/byh023

Tosun, M.S., \& Abizadeh, S. (2005). Economic growth and tax components: An analysis of Tax changes in OECD. Applied Economics, 37(19), 2251-2263. DOI:10.1080/00036840500293813 


\section{ODNOS IZMEĐU POREZA I EKONOMSKOG RASTA: PRIMER SRBIJE I HRVATSKE}

\section{Rezime:}

Ova studija predstavlja empirijsku analizu poreza i ekonomskog rasta u Srbiji i Hrvatskoj u periodu 2007-2016. Kako bi se utvrdio uticaj poreskih oblika na ekonomski rast i njihov odnos, autori su postavili panel regresioni model gde je bruto domaći proizvod zavisna varijabla, dok su porez na dobit preduzeća, porez na dodatu vrednost, doprinosi za socijalno osiguranje i akcize nezavisne varijable. Rezultati modela slučajnog efekta prikazuju pozitivan uticaj poreza na dobit preduzeća, poreza na dodatu vrednost i doprinosa za socijalno osiguranje, dok akcize negativno utiču na bruto domaći proizvod. Međutim, samo porez na dodatu vrednost ima statistički signifikantan uticaj na ekonomski rast u ovim zemljama, pri čemu svako povećanje prihoda po osnovu ovog poreza doprinosi rastu bruto domaćeg proizvoda u posmatranom periodu.

Ključne reči:

porezi,

ekonomski rast, odnos, Srbija, Hrvatska. 